\title{
The Study of African Musical Contribution to Latin-America and the Caribbean:
}

\author{
A Methodological Guideline
}

(N. E.: Em 1989, O CIDEM, Conselho Interamericano de Música da Organização dos Estados Americanos, convocou uma reunião em Caracas de diversos pesquisadores da música latino americana e do Caribe de influência africana. Foi eleito uma "Grupo de Trabajo" de cinco participantes que voltaria a se encontrar em data posterior para a discussão de idéias e diretrizes a serem tomadas por pesquisas sobre esse assunto.

A comissão reuniu-se na Universidade de Kent nos Estados Unidos em outubro de 1990, com formação diversa daquela escolhida na reunião de Caracas, editando o seguinte documento, publicado por solicitação do organizador do encontro, Dr. Kazadi Wa Mukuna)

Research and documentation of Africanism in Latin America and the Caribbean has too often been focused on the distinction of what is and is not African in the New World. This approach has in many cases left misleading and stereotypic ideas that whatever is "exotic" and is not understood came from Africa. To believe that what survived in Latin America is pure African, is to say that all Africans have the same cultural background. This cannot be sustained on the grounds of cultural diversity of this continent.

On the other hand a superficial comparison between cultural traits in Latin America with those from today's Africa, may lead to false interpretations. Those who hold this theory tend to dismiss the fact that Latin American history envolved differently and independently from that of Africa.

More recently other approaches have been defined from the conceptual level of carriers of cultural material. In music, this conceptual level must be envisioned to provide a deeper understanding of persistence and continuity of African musical elements in the new society.

The identification of African elements in the musical fabric of Latin America should also take into consideration the historical aspect which includes the impact of all phenomena, social and economic, on the carriers of the cultural material. This sustains the fact that a musical expression is indeed a product of the influence of these phenomena on the conceptual level of its makers. To the later, music is not conceived as mere organization of sounds, but rather as integral parts of a total expression, which include languages, dances, movements, games, and special behaviors, pertaining to a dynamic society. The nature of the proposed methodology is an interdisciplinary which brings together approaches of disciplines in social sciences and the humanities. 
One should not speak of African music, when referring to musical expression produced in societies outside of the African continent, although the new musical expression may be structured according to the principles of organization of African music. While the Genesis of the Latin American or Caribbean society may indicate the African, European, Amerindian, and other origins of its components, it began to have its own history from the moment the many groups became an integral part of the new society. The same way that the individuals became part of their societies, no longer being Africans, the music is an expression of the new cultural context, conforming to the new norms, which are necessary for its continuity.

Therefore scholars are compelled to recognize and to distinguish between the principles of creation from those of innovation. The principle of innovation implies that constituent components of a musical expression can be modified or replaced by others independently from each other. This happened during history untill the present time and fits perfectly into the concept of the continuity of cultures. Creation, on the other hand, suggests that all of the components which originally composed the total of musical expression, are replaced by new ones. When these two principles have been distinguished and defined within their conceptual framework, africanisms in the musics of Latin America and the Caribbean can be evaluated in their proper historical, social, and cultural dimensions. 